\title{
“Are We There Yet?" Is Health Care in England Really on the Road to Privatization?
}

\author{
Alex Waddan \\ Associate Professor \\ School of History, Politics and International Relations \\ University of Leicester \\ Leicester, LE1 7RH \\ United Kingdom \\ aw148@leicester.ac.uk
}

\begin{abstract}
In 2010 the Conservative led Coalition government promptly set about reform of the English NHS. Opponents denounced the resulting legislation, the Health and Social Care Act of 2012, as hastening the beloved NHS towards privatization. This was now a familiar refrain as a number of reforms from the late 1980s onwards had provoked the same critique. This paper asks whether the HSC, building on those previous reforms, did finally set health care arrangements in England on the road to privatization. This question raises the conceptual problem of measuring change, which is particularly problematic in the multi-tiered field of health policy where "privatization" means different things to different stakeholders. In order to provide an organizing framework this paper combines the literature on policy change with that on health care systems. The latter literature has identified three dimensions of health care arrangements: The financing of care, the provision care, and the regulation of care. The paper suggests that the HSC, building on previous reforms, reinforces the emergence of different policy trajectories with regard to privatization across these three dimensions
\end{abstract}




\section{“Are We There Yet?" Is Health Care in England Really on the Road to Privatization?}

The United States is not the only country to find its health care arrangements at the center of political debate. The United Kingdom too has seen increasing argument over whether its health system is being fundamentally re-ordered. The health care wars in the UK have not seen conflict as ferocious as over the Affordable Care Act as all major parties publicly agree on the need to preserve the state run National Health Service (NHS) as the core element of the UK's health care delivery, but opponents of recent change insist that the system is in fact being surreptitiously, but steadily, privatized and moved away from its socialized roots. Generally, reform advocates simultaneously claimed to be making necessary changes while preserving the basic values of the NHS. Critics, however, talked of an NHS moving away from its treasured principles. ${ }^{1}$ Unsurprisingly arguments over privatization started with reforms enacted in the Thatcher era, outlined in the controversial White Paper, Working for Patients, ${ }^{2}$ which aimed at creating an internal market within the NHS. Yet, while the Labour Party denounced these changes, positioning itself as the defender of the traditional NHS, some critics on the left later complained that one thing that was 'new' about the New Labour governments of the 2000s was that they too encouraged private sector involvement in the NHS. ${ }^{3}$ In the build-up to the 2010 general election, with the NHS remaining overwhelmingly popular, both parties campaigned as the service's champions. ${ }^{4}$ In particular, the Conservative Party leader, David Cameron, was anxious to distance his party from the perception that it was less 
committed than Labour to the NHS. ${ }^{5}$ As Prime Minister, however, he found his government quickly engulfed in controversy over NHS reform.

If not matching the firestorm surrounding the enactment and implementation of "Obamacare", the passage of the Health and Social Care Act of 2012 (HSC), after a prolonged legislative process, reignited the debate about whether health care arrangements in the UK, and more specifically England, are effectively being privatized. ${ }^{6}$ (The emphasis on England is critical here, with devolved powers meaning that the HSC did not fully apply to the other constituent nations of the $\mathrm{UK}^{7}{ }^{7}$ ) Cameron insisted that the HSC did not challenge the fundamental principles of the NHS, but by the time of the 2015 general election Labour leader Ed Miliband maintained that the changes opened the door to privatization. ${ }^{8}$

But, just as "socialized" has become a refrain so misused that it has been divested of much of its explanatory value in US debate, so the term "privatization" often confuses rather than clarifies discussion in the UK. As Martin Powell and Robin Miller reflected, the "term privatization is multidimensional, and definitions of the term are often implicit, unclear, and conflicting" resulting in "a Tower of Babel."9 Yet, it is important to persevere with efforts to establish an organizing framework to assess the direction of change that has taken place. Is English health care really on route to privatization?

Before offering a definition of "privatization" and mapping the empirical evidence against criteria arising from that definition, it is important to frame any investigation into degrees of change. Questions about how to measure change and define significant or path departing change have long puzzled scholars, and are particularly problematic in health policy where change, or the reinforcement of existing structures, impacts quite differently on the diverse array of stakeholder 
constituencies with an interest in policy development. ${ }^{10}$ One way to filter potentially conflicting evidence and competing perspectives is to combine the literature on policy change with that on health care systems.

The latter literature has seen scholars develop "ideal types" with regard to the respective roles of state and market in the organization of health care, and the resulting typologies provide a means of categorizing different health care systems. ${ }^{11}$ In this context, the UK health care system, along with that in the US, has traditionally been cast as a distinctive representative of a particular type. In the mid-1980s the OECD described the US and UK as "prototypical country examples" of private and "Beveridgian" systems, with the US's arrangements emphasizing “consumer sovereignty" and the UK's prioritizing "social equity" with the "former being characterised by incentives, the latter by control." 12

Other studies have also consistently placed the UK in the ideal type most strongly emphasizing the state's role. ${ }^{13}$ Yet, does the accumulation of reforms, from Thatcher through Blair and on to the HSC of 2012, test the continuing legitimacy of this categorization of health care in England? Do English health care arrangements still prioritize "social equity" with a dominant state leaving little role for the private market, or has there been a turn towards market incentives? The answer to this question is complex. If any of the reform packages had changed the rules by which residents in England qualify for NHS treatment by, for example, introducing a means test, then such a move would have been path breaking. But such highly visible moves have not occurred. In 2013, then Prime Minister David Cameron presented himself as a champion of the traditional values of the NHS, which remained "this great national treasure." These sentiments reflect the continuing high levels of popular support for the NHS, as summarized by the pollsters Ipsos Mori, "People continue to be 
extremely proud and positive about the NHS. The majority think Britain's National Health Service is one of the best in the world and perceptions that the NHS provides good value for money are stronger than ever."14

Yet it is important to recognize that significant change can take place that falls short of a paradigm shift. ${ }^{15}$ The accumulation of enough incremental shifts can add up to something more than is suggested by an incremental approach. ${ }^{16}$ Thus, while neither the HSC nor the earlier reforms in themselves constituted abrupt regime, or ideal type, change, their provisions might still disrupt the existing institutional settlement in important ways, which, in the longer term, might establish an entering wedge for further expansion of private sector intervention in health care organization. The use of incremental reform to bring about change, rather than attempting comprehensive revision, is a particularly important tool when the policy institution being reformed is as popular as the NHS. In this context, one strong critic of trajectory of reform initiatives, Calum Paton, argues that policy developments from the late 1980s onwards were marked by "frequent decision-points" that demonstrated "at least neo-liberal symbolism" and "increasingly over time" manifested "neo-liberal substance." This process occurred "messily" and involved "periods of stasis" and "even partial reversal", but it moved on "relentlessly over time.",

When assessing Paton's argument it is important to look beyond examples of formal revision of health care policy and to consider less public modes of change. There was never a declared "neo-liberal" policy agenda to redefine the NHS, but scholars have identified how change can come about through means such as policy layering, which sees new rules added to existing ones rather than explicitly replacing them; or policy drift, whereby failure to update policy in line with changing socioeconomic circumstance renders existing policy less effective over time, or policy 
conversion whereby existing policy is re-routed. ${ }^{18}$ The importance of these types of policy change has been tested in studies of US health care development, ${ }^{19}$ but has not been so rigorously applied to the English case. As demonstrated by those studies of the US, applying this analytical framework helps gauge the importance of different aspects of policy change and, despite the institutional differences between the two countries, thinking of these various types of change can provide similar insight in the English case.

Before drawing on these tools to investigate Paton's conclusions, it is important to outline the literature about health system organization to provide a systematic framework for analysis and to explore what is meant by privatization.

\section{THE THREE DIMENSIONS OF HEALTH CARE AND PRIVATIZATION}

The OECD study focused on the proportion of overall health care spending that was government spending and whether that public money came from general taxation revenues or from social insurance funds. ${ }^{20}$ It also asked whether a nation's health care arrangements prioritized social solidarity or individualism in terms of access to care and whether public or private providers supplied that care. Further work has identified three broad dimensions of health care organization. ${ }^{21}$ First, the funding and terms of eligibility for care. What is the balance between the state and the private sector in paying for care, and is care offered on a universal basis, or does it depend on previous social insurance contributions or a means test? Second, is "ownership" of service provision primarily in the public or private sector? Are medical staff public employees and are hospitals publicly owned? Third, the regulation of care; how does the state regulate the relationship between the payer for care and both the providers and beneficiaries of care? And, how does the state intervene in the relationship between providers and beneficiaries? 
Having identified these three dimensions the next step is to establish what would constitute "privatization" in each dimension. First, with regard to funding and access, privatization would involve a shift from public to private sector payers or, with respect to the NHS, a move away from its universal terms of access. Policy change on either of these fronts would involve some individualization of risk. On the second dimension, privatization could entail a transfer in the ownership of assets; for example, public hospitals might be sold to private investors. A softer form of privatization might involve the state outsourcing work previously done in the public sector to the private sector. The final dimension, the regulation of care, is the most difficult to conceptualize in terms of privatization as there are no direct quantifiable measures such as spending or hospital ownership, yet it is important to think about how policy change with regard to the state's regulatory role might encourage, or put up barriers to, privatization. Privatization could take the form of de-regulation or changes in the rules governing the balance of power between different stakeholders that foster more market style incentives. For example, a shift from a hierarchical relationship, where the state tightly regulated the behavior of both patients and providers leaving them with few choices and little control over costs, to a set of arrangements granting autonomy, allowing patients to choose their preferred provider, thus enabling them to act as consumers rather than simply as recipients of care, or allowing providers to compete with each other on the basis of price, would indicate a shift from state control to market incentives.

When attempting to judge policy change across these dimensions and the extent of a shift towards privatization it is important to recognize that "one dimension does not necessarily determine the other two, and that non-uniformity across dimensions can also arise". ${ }^{22}$ It should also be acknowledged that the boundary lines 
between the three dimensions are blurred, especially with regard to the impact of changes to ownership of provision and regulation. For example, the state might outsource some care from public to private providers, but then strictly control the behavior of those private providers. Along the second dimension this would constitute privatization, but a side effect would be an increase in the regulatory role of the state. Alternatively, a hospital might remain in the public sector, but the government might end an existing guarantee of financial support and leave the hospital to act as an independent financial unit. This would leave the status of the hospital unchanged in the second dimension, but the economic incentives for the hospital managers might be considerably changed. ${ }^{23}$ This suggests that matters are unlikely to be clear-cut. As Paul Starr notes, "The spectrum of alternatives runs from total privatization (as in government disengagement from some policy domain) to partial privatization (as in contracting out or vouchers)." Hence, "the implications of privatization vary with its degree." 24 The task now is to examine the empirical evidence and tease out those implications.

\section{The Funding and Access Dimension}

The post war Labour Government fundamentally re-ordered health care arrangements in the UK: "The NHS created an extraordinary and unprecedented economy more or less independent of the surrounding marketplace, in which health care, previously a highly valued commodity, was suddenly available to everyone at zero price". ${ }^{25}$ The new system was financed by the state, very largely through general taxation, with no charge to patients at the time of treatment for everyone "ordinarily resident" in the UK. Sixty years on that remained the same. ${ }^{26}$ Of aggregate NHS spending in 2008, 79.7 percent came from general tax revenues, 19.1 percent from National Insurance contributions and 1.2 percent from patient charges (mostly arising from out-patient 
prescription charges and payments for dental services). ${ }^{27}$ The use of NI contributions (the UK's version of social insurance) did not have any relevance in terms of access to care. Demonstrating "social equity", the NHS reached its $60^{\text {th }}$ anniversary providing equal access to "free at the point of use" primary and secondary care NHS services, with no discrimination based on a person's employment record or tax contributions or, equally with regard to the system's universality, no means testing to deny the wealthy these public goods. ${ }^{28}$

These funding arrangements remained unchanged by the reforms of the 1990s and 2000s and, when it announced its reform plans in 2010, the Coalition government insisted that the "values and principles of the NHS", defined as a "comprehensive service, available to all, free at the point of use and based on clinical need, not the ability to pay", would be untouched ${ }^{29}$ In this sense, the universalism and "social equity" of the NHS were reaffirmed. Moreover, the proportion of UK total health care expenditure that is public expenditure remains relatively high. In $2013,83.3$ percent of current health care spending in the UK was public expenditure against an OECD average of 72.7 percent, with the proportion of overall health spending that was public spending being higher in the UK than any other G7 country. ${ }^{30}$

Still, a high relative level of public spending and equal access to care is subtly different from actually accessing care: And rationing of care has been inherent to the operation of the NHS as government allocates a budget for NHS spending, bringing a constant dilemma about what that budget should be and, given that all needs cannot be satisfied, how most effectively to ration the care that is provided. This rationing does not violate the principle of "social equity" as it is scarcity resulting from the state's fiscal logic, rather than discriminating against individuals on the basis of their personal circumstances. Yet, even if the rationing is non-discriminatory and largely 
hidden there is one public manifestation that causes political unease. As Tony Delamothe explains: "Of the varieties of 'surreptitious rationing' adopted by Britain to limit access (delaying, deferring, deterring, dissuading, declining), only waiting lists (rationing by delay) gave visibility to the underlying scarcity." ${ }^{31}$ Here, it is important to remember that the NHS is not a monopoly and if people are not prepared to wait for treatment then there is a private pay sector. One possible, subterranean, means of undermining the "free" NHS and encouraging the private pay sector might be through a gradual process of underfunding the NHS and exacerbating delays in how quickly people get treated. If rationing, as a consequence of demand for care outstripping NHS supply, becomes ever more severe, this could constitute a type of "policy drift", ${ }^{32}$ effectively constituting policy change as people's frustration with NHS delays led to increasing use of the private pay sector.

Such a scenario would constitute a process of creeping privatization and through the 1980s there was growth in private pay elective secondary care as "expenditure on private inpatient care saw an annual real growth of between 11 and 36 percent". ${ }^{33}$ More recently, however, there has been little evidence of a shift from public to private sector spending. Private sector spending, combining everyday out-ofpocket spending by individuals on pharmaceuticals and medical appliances, the private medical insurance sector and spending by charities, measured in current pounds sterling, did increase "from $£ 10.8$ billion in 1997 to $£ 25.1$ billion in 2013 ". Yet that rate of growth was slower than the increase in public sector spending over the same period, which rose from $£ 44.1$ billion to $£ 125.5$ billion. ${ }^{34}$ It is also important to understand the limited scope of private insurance in the UK:

"Roughly 11 per cent of the UK population has some form of private medical insurance. That figure, however, gives a misleading impression as far from all 
of that cover is comprehensive. Few policies, whether company-paid or provided, or individually paid, offer maternity or mental health cover. None provide cover for accidents and emergency or for general practice". 35

Importantly, the Labour governments led by Blair and Brown explicitly increased the rate of real growth of public expenditure on health care. In 2000 current expenditure on health care accounted for 6.3 per cent of UK GDP (government spending being 5.3 per cent). That compared with 8.3 percent in Canada, 9.5 percent in France, 9.8 percent in Germany, and the outlying 12.5 percent in the US. ${ }^{36}$ At that time, however, Prime Minister Blair pledged to bring UK spending on health care up to average EU levels. Even if not achieving that goal, there was a significant jump in the UK's public health care spending, reversing any previous trajectory suggesting policy drift. The Institute for Fiscal Studies, reported, "From April 1979 to March 1997 UK NHS spending rose at an average annual real rate of 3.2 per cent. Between April 1999 and March 2008 spending on the NHS grew by an average 6.3 per cent a year in real terms". ${ }^{37}$ Thus health care spending reached 7.9 per cent of GDP in 2008 (government spending being 6.5 per cent). ${ }^{38}$ Hence through the 2000 s there was a renewed commitment to the public funding of a public health service across the whole of the UK that was dedicated to "social equity". The rate of spending growth did stop following the Great Recession, but the NHS was spared the severe austerity imposed on other government spending departments. The real annual growth rate of public expenditure on health per capita fell into negative territory from 2009 through 2012 before rising again in 2012-13. ${ }^{39}$ The private pay sector, however, at least in the short term, did not benefit from any excess demand created by the end of real term growth in public health expenditure. As the private health care analysts and consultants LaingBuisson acknowledged: 
"The private pay share of healthcare markets ... took a fairly steep dive from $5.9 \%$ in 2009 to $4.8 \%$ in 2014 , driven by the recession ... as private demand proved vulnerable to reductions in disposable income". ${ }^{40}$

Thus the private pay sector has been stuck somewhere between stagnation and marginal decline over the last twenty years, giving no hint of a privatization, creeping or otherwise, in the funding of health care across the whole of the UK.

At this point, it is important to note how two policy options, which would have incentivized people to use the private sector and that had previously been official Conservative party policy, were not incorporated into the HSC. First, providing tax relief for people buying private medical insurance had considerable support amongst Conservative MPs in the run-up to the 2010 election, ${ }^{41}$ and a limited version, whereby individuals aged over 60 could get tax relief on private insurance, had been introduced in 1990 before being abolished by the Labour government in 1997. Second, the Conservative Party manifesto for the 2005 general election had included a plan that became known as the "Patients Passport". ${ }^{42}$ Little understood, this proposal constituted "a promise to break with more than 50 years of history and to offer patients and the private sector a direct subsidy if patients choose to leave the NHS and go private". ${ }^{43}$ Such a move would clearly have "put the principle of equity at risk". ${ }^{44}$ Soon after becoming Conservative party leader, however, David Cameron declared that his party had spent too much time thinking about how to move people from the NHS into the private sector, citing as examples, "Margaret Thatcher's support for giving tax relief on private medical insurance, and our patients passport policy at the last election". In an apparently unequivocal endorsement of "social equity" he insisted that the "primary purpose" of the service "is to secure for every single person in this country free access to high quality healthcare". ${ }^{45}$ 
Overall, whatever one's views on Cameron's integrity when declaring his "love" for the NHS, the various efforts to reconfigure the NHS, from Working for Patients through to the HSC, did not challenge the principle of state funding of current NHS spending, nor, after 1997, were there policy initiatives designed to encourage people to shift to the private pay sector. In short there has been no path departing moment in this critical dimension of the English health care system and there seems to be little evidence yet of any privatization by subterranean means.

\section{The Provider Dimension}

The public funding of the NHS never meant that everything within the NHS framework was part of the public sector. GPs, as primary care providers, were always independent contractors with the NHS rather than salaried employees, but ongoing arguments about privatization revolve around the increased role of the private sector in providing NHS secondary care: And while Cameron was keen to assert his support for the principle of "social equity", he also made it clear that he wanted to encourage private sector providers to compete with state providers to treat NHS patients with NHS funds: "Instead of helping a few to leave the NHS and go private, we want the private sector to come and help improve the NHS for everyone". ${ }^{46}$ Four years later, promoting that goal was central to the government's plans: “Our aim is to free up provision of healthcare, so that in most sectors of care, any willing provider can provide services, giving patients greater choice and ensuring effective competition stimulates innovation and improvements, and increases productivity within a social market". ${ }^{47}$ But this "aim" was not a new policy idea as the previous Labour governments had embraced the principle that private sector involvement in provision would generate efficiencies and expand capacity. 
In hindsight, the path breaking moment with regard to the provider stream had come in the late Thatcher era. Working for Patients laid out a vision for reform, which was then broadly enacted in the 1990 NHS and Community Care Act. ${ }^{48}$ In a formal revision of policy, a divide was created between purchasing agents and secondary care providers, aiming to create an internal market so that NHS secondary care providers had to compete with each other for funding rather than being able to rely on a guaranteed stream of patients and income. The plans were denounced by Robin Cook, then the Labour Shadow Secretary for Health, as a move towards "market medicine as it is practised across the Atlantic" and critics pointed to the "Americanizing" influence of Alain Enthoven, who had advised the government in the mid-1980s that greater efficiency in the NHS would follow from more emphasis on money following patients. ${ }^{49}$

The immediate impact of the reforms should not be exaggerated. While elements of market structures were introduced, the incentive structures were weak and limited. Moreover, when Labour won office in 1997 the new government promised to undo the Tory policies, suggesting that the marketization project was to be shortlived. ${ }^{50}$ The NHS Plan, issued in July 2000, maintained that the internal market had failed because "Competition between hospitals was a weak lever for improvement" and, furthermore, the "market ethos undermined teamwork between professionals and organisations vital to patient-centred care". ${ }^{51}$ Yet, even while rejecting a market approach the government encouraged greater NHS use of private sector care facilities. The document referred to "partnership" rather than competition but insisted the "decades" long "stand-off between the NHS and the private sector providers ... has to end. Ideological boundaries or institutional barriers should not stand in the way of better care for NHS patients". 52 
By 2002, while the Government still avoided specific references to competition between providers, there was greater emphasis on ending "perverse incentives" that saw "poorer performers in the NHS ... often bailed out" and on introducing "a new system that rewards good performers". ${ }^{53}$ This was to be brought about by giving the principal commissioning function to bodies called Primary Care Trusts (PCTs) that were "to purchase care from the most appropriate provider - be they public, private or voluntary" in order to "promote diversity in supply". ${ }^{54}$ In addition, private sector providers were given further opportunity to perform routine treatments for the NHS as PCTs were encouraged to use privately run Independent Sector Treatment Centres (ISTC). The integration of ISTCs into the NHS framework can be seen as a classic case of 'policy layering' since these new organizations were added to the existing institutional structures rather than explicitly, and likely much more controversially, replacing part of that framework.

ISTCs were innovative in two ways. First, unlike other private providers receiving NHS funds, they were established as a direct consequence of government policy. Second, despite being in the private sector, ISTCs only treated NHS patients with NHS funds. Nevertheless, critics saw the use of ISTCs as furthering a privatization agenda, ${ }^{55}$ especially as these new providers were encouraged to enter the market with incentives, offering payments above the NHS tariff for performing the relevant treatments, in ways that were not always transparent. ${ }^{56}$ Whatever language the government chose to frame these policy initiatives, the turn to private sector providers marked "the revival of the marketplace for care". ${ }^{57}$ In short, the Labour government, by contracting out NHS work to the private sector, further pushed open the door left ajar by the entering wedge that divided purchasers and providers. 
Initially, some advocates of competition on the supply side complained that the market had not been properly opened up, thus restricting the beneficial effects that would come from genuine competition, but subsequent evidence suggests that there was some increase in private sector penetration into the NHS provider-chain. ${ }^{58} \mathrm{In}$ constant 2011/12 prices, total NHS spending in England on services provided by nonNHS providers increased from $£ 5.6$ billion in $2006 / 07$ to $£ 8.67$ billion in $2011 / 12 .{ }^{59}$ The majority of this spending was commissioned by PCTs for secondary care meaning that over this period "the proportion of the PCT secondary care budget accounted for by non-NHS providers rose from $9.0 \%$ to $12.3 \% "{ }^{60}$ The overall numbers include spending on services provided by the voluntary sector and local authorities, but payments to independent sector providers, which include ISTCs and other private providers, overwhelmingly accounts for the increase. In addition, looking at overall spending gives a potentially misleading picture inasmuch as there is considerable variation in the role of private providers across the sector. There is minimal private provider involvement in accident and emergency or maternity care, but in "2010/11, ISTCs accounted for 17 per cent of hip replacements, 6 per cent of cholecystectomies (gallbladder removals) and 17 per cent of elective unilateral inguinal hernia repairs funded by the NHS", ${ }^{61}$

Thus the HSC of 2012, in seeking to encourage marketization and competition in the English NHS amongst providers, public and private, was not breaking new ground. The changes introduced by the Blair governments already "represented a major attempt to improve an iconic public service using market-related incentives", ${ }^{6}$ Hence, in terms of policy change, the HSC, which sought to encourage commissioning agents to be more pro-active in considering alternative providers and to intensify competition amongst those providers, should be seen as policy layering 
upon layering. The HSC's legislative progress was in fact halting, with some dilution of the original plans, ${ }^{63}$ but there was movement towards the goals stated in the 2010 White Paper whereby "Autonomy in commissioning" would be "matched by autonomy for providers". ${ }^{64}$ Despite the evidence that previous reorganizations had undermined efforts to generate the efficiencies envisioned by the original purchaser provider split, the commissioning process was to be changed again with PCTs to be replaced by bodies called Clinical Commissioning Groups (CCGs), whose membership included some GPs. ${ }^{65}$ All NHS hospital and community services would become self-governing Foundation Trusts. These would remain in the public sector, but would be in competition with each other as well as providers from the private and voluntary sectors and needing to convince commissioners of their quality. Hence, public sector providers were subject to increased economic risk, partially at least, because of competition from the private sector.

This increase in contracting out NHS work to private providers and the increased commercialization of NHS providers, creating a "mixed economy of care", ${ }^{66}$ do constitute steps along a continuum from a nationalized to a privatized industry. These steps, however, did not mean that the state was relinquishing its responsibility to provide providers. A more explicit shift towards privatization would involve the state selling off NHS assets to the private sector and then abdicating its responsibility for future outcomes, but this 'hard' form of privatization has not occurred.

There was, however, another policy shift, which, while it did not involve selling public assets, did see a new hybrid model of ownership of new hospital infrastructure emerge. The private finance initiative (PFI), introduced by the Conservative government in 1992, can be seen as an example of policy layering, as it 
provided an alternative way of funding public sector infrastructure development. Rather than directly using tax revenues to pay private companies to build roads or schools or hospitals, PFI was championed as a means of sharing the risk between public and private sectors and drawing more extensively on private sector management expertise as private companies would not only build but also pay the initial costs of these new schemes. ${ }^{67}$ In the case of hospitals these were then "rented" back to the public sector with repayments typically made over a 25 to 30 year period, though sometimes considerably longer. Although a Conservative initiative, PFI was enthusiastically embraced by Blair to fund hospital building. It was justified as a means of improving public sector facilities at a point when the public finances could not sustain the necessary spending, but by 2010 there was already widespread skepticism about the efficacy of the PFI deals as it became increasingly evident that many hospitals were due to pay back multiple times the original investment. In fact, following a critical report by the House of Commons Treasury Committee (2011) on the overall use of PFI, the Coalition government announced that it was to restructure the procurement process to protect the taxpayer. ${ }^{68}$

It is beyond the scope of this paper to judge the wisdom of using PFI, but what is pertinent is that the state sought the collaboration of the private sector to perform a task, funding hospital building, that it had previously managed for itself. In turn, this potentially diverted funds from patient care in those hospitals to make the repayments to private investors. ${ }^{69}$ The evidence suggests that PFI was a damaging financial deal for a number of NHS institutions with some Foundation Trusts facing long-term fiscal burdens due to decisions made in the 2000s. Nevertheless, it is important to stress the limited step this constituted towards privatization as PFI funding did not 
create "private" hospitals. These facilities were part of the NHS framework and the relationship between hospital and patient was no different from other hospitals.

\section{The Regulatory Dimension}

The organizational hierarchy regulating health care in England, including the NHS and the private pay sector, has undergone a plethora of changes since the 1990s with various bodies created, disbanded and reconfigured over time. It would be impossible and is unnecessary to chart all those changes here. Clearly, it is critical that any health care system demand high standards of care, and it would seem likely that rigorous scrutiny is likely to lead to better maintenance of those standards, but the standard of that scrutiny is not, per se, a driver in a nationalizing or privatizing direction. Thus, while there is some evidence that the changes have diminished the state's capacity to inspect provider standards effectively, with potentially damaging consequences, a weaker inspection regime applies to both public and private providers: And importantly responsibility for conducting checks was shifted between different state bodies rather than handed over to a private agency. ${ }^{70}$

This analysis of the regulatory dimension, therefore, is not designed to look at all aspects of regulation, but focuses on particular instances of policy change, or continuity, which have enabled, or put up barriers, to a process of privatization. The evidence is contrary with diverse impulses about the appropriate roles of state and market on display. This was especially the case through the tenure of the Labour governments of the 2000s. While happy to expand the role of private providers doing NHS work, the Blair government simultaneously restricted how much income NHS hospitals could make from treating privately paying patients. This relates to an idiosyncrasy embedded in the NHS at its foundation, which was to allow hospitals in this public health service to set aside beds to treat privately paying patients. In 2002 
there were approximately 3000 private beds in NHS hospitals treating about 120,000 patients a year. Then Health Secretary, Alan Milburn, queried the continuing logic of this arrangement, ${ }^{71}$ and, while pay beds were not abolished, in 2003 new rules stipulated that the private income Foundation Hospitals could generate would be capped at the level they reached in 2006, which for most hospitals was about 2 percent of income, though with some variation, especially in London. Overall, through 2000s the NHS's share of the private pay market declined sharply: In "2011, the NHS accounted for just an 8 per cent share of all private revenue in UK hospitals; the comparable figure in 1997 was 16 per cent". ${ }^{72}$

The Labour government also sent mixed messages to providers about the scope of their independence. Hospitals were expected to exercise greater financial autonomy, but professional autonomy was restricted through the imposition of a "wide variety of targets coupled with heavy performance management". ${ }^{73}$ While controversial, the use targets did help reduce waiting times, ${ }^{74}$ but represented a strategy based on "command and control" rather than "choice and competition". 75 There was more consistency with regard to the regulation of the relationship between providers and patients, with the latter given more opportunity to choose between the former: Treatment was no longer to be "handed down", with patients given a choice of secondary care provider from a national directory from $2008 .{ }^{76}$ Offering patients choice is not, per se, a privatizing act, but consumer choice is key to the operation of private markets.

On the other hand, the preliminary evidence suggested that the implementation of choice had not resulted in a great deal of exercise of choice. While patients valued the concept of choice, most chose their local provider and very few made use of the available information about hospital performance. ${ }^{77}$ One objective of the Coalition 
government in setting out the HSC was to make "choice" a more meaningful driver of behavior by "making information systems more accessible, relevant and wellstructured". ${ }^{78}$ There has long been doubt that patients can behave like informed consumers given the asymmetry of knowledge between patients and medical professionals, ${ }^{79}$ but if GPs act as interlocutors helping patients make an informed choice of secondary care provider, the various changes do combine to place market pressures on providers. Especially given the increasing financial autonomy granted to (or forced upon) hospitals operating as Foundation Trusts, the need to compete for "customers" means that patients will have an enhanced capacity to behave as "consumers".

The promotion of patient choice by Labour governments through the $2000 \mathrm{~s}$ and the following Conservative-led Coalition was a very public aspect of policy change, though it was never flagged as contributing towards a privatizing agenda. Less well known and understood was the creation and evolving role of a body called Monitor. A formally independent body, but supported by the Department of Health, Monitor was established in 2004 to regulate the fiscal robustness of Foundation Trusts. In what might be seen as an act of policy conversion, this function was expanded by the HSC to include helping set prices for NHS services with a new focus on "enforcing rules to prevent anti-competitive behaviour by healthcare commissioners and providers". ${ }^{80}$ This language was in fact a slight retreat from the text of the 2010 White Paper that talked of Monitor having "proactive" power to promote competition, but that adjustment did not allay the fears of those who saw Monitor's altered remit as designed to promote greater private sector involvement in the delivery of NHS services at the expense of NHS providers. ${ }^{81}$ 
An example of how these various changes could interact came in the autumn of 2013 when Monitor launched its first post-HSC investigation into whether a CCG was fully informing patients about private secondary care options. Spire Healthcare Limited complained that two CCGs in Lancashire had directed GPs to advise patients to choose the NHS provider rather than the Spire private hospital for NHS funded treatment. ${ }^{82}$ The specifics of Spire's case were not upheld, but Monitor did rebuke the CCGs for not ensuring that choice was properly offered to patients. A statement by the executive director of co-operation and competition at Monitor read: "Patients have legal rights to make choices about aspects of their NHS care and commissioners have an important job to do making sure that patients are offered a choice by their GPs". ${ }^{83}$ The ambition for "empowering patients" was reinforced in the long-term strategy document produced by NHS England in October 2014, which noted that half of patients still said that they were not being offered a choice of hospitals for their care. ${ }^{84}$ Tracking the impact of the extended choice agenda and surveying the extent to which GPs do encourage their patients to shop around for secondary care providers, potentially passing more NHS work to private providers, is an important area for continued research.

The changes to policy described so far to the regulatory dimension of care, if halting and uncertain in the effectiveness of their implementation, can be seen as prerequisites to the further privatization of care. On the other hand, there were important elements of relative continuity in policy that maintained barriers preventing additional penetration of private market values and practices. First, the state still regulates who can access the market with providers needing to be accredited by the CQC. Second, providers of secondary care compete on quality but not price, which runs contrary to the expectations of a functioning private market. The language in the 2010 White 
Paper raised some concerns that price competition would be introduced, potentially allowing private providers to undercut the NHS tariff for secondary care, cherrypicking the routine elective procedures, leaving the NHS providers with the expensive and complex. ${ }^{85}$ Eventually the Department of Health clarified that competition by price was not on the agenda, and so all providers continue to be bound by the system of Payment by Results that "covers the majority of acute healthcare in hospitals, with national tariffs for admitted patient care, outpatient attendances, accident and emergency (A\&E), and some outpatient procedures." ${ }^{86}$

Third, the state remains final arbiter of what treatments will be funded by the NHS at all, as the HSC reinforced the role of the National Institute for Health and Clinical Excellence (NICE). NICE, established in 1999, has a variety of functions in terms of offering guidance about clinical practise and medical technologies as well as setting the framework for performance measurement. ${ }^{87}$ Its most controversial role is to advise on the cost-effectiveness of drugs for NHS use. This makes NICE potentially a powerful arm of the state, if somewhat separated from the government of the day. Importantly, whatever the merits of this form of rationing, NICE's role reinforces the principle of equity across the NHS:

"Technology appraisals assess the clinical and cost effectiveness of health technologies ... This is to ensure that all NHS patients have equitable access to the most clinically - and cost-effective treatments that are viable". ${ }^{88}$

On the other hand, these important aspects of policy continuity need to be set against a policy change introduced in the HSC, which does have potential to promote fee paying practise at the expense of public sector patients. This was also a change that illustrated the importance of the switch in partisan power following the 2010 election. In what can be seen as an act of policy conversion the government maintained the principle of imposing a cap on the proportion of income NHS 
hospitals could generate through private sources, but transformed the intent of previous Labour government's actions by raising that cap to 49 percent of income. The trade association for Foundation Trusts supported the initiative, claiming, "nonNHS income allows trusts to offer NHS patients services and innovations which might not otherwise be available within the current NHS financial envelope". ${ }^{89}$ But Andy Burnham, Labour's Shadow Health Secretary, denounced the move as turning “our precious NHS into a US-style commercial system, where hospitals are more interested in profits than people". ${ }^{90}$ The early evidence is that some hospitals have significantly increased their income from private patients. ${ }^{91}$ This trajectory was particularly evident in London hospitals; for example, the Royal Brompton Hospital Trust increased its income from private patients by 37.7 percent between 2011-11 and 2013-14. On the other hand, across the whole of the English NHS, there was very little shift with private income accounting for " $0.69 \%$ of overall provider income in England $2012-13$, rising slightly to $0.7 \%$ in $2013-14$. It stood at $0.71 \%$ in $2010-11$ and $0.68 \%$ in $2011-12 \% .92$

\section{DISCUSSION}

Rudolf Klein emphasizes that the "defining characteristics" of the NHS have persisted, since it remains a "publicly funded service, freely available to all."93 In this context, the funding and access stream provides the most clear cut evidence of this article's analysis, as there has been no policy change over the last 25 years, either in the shape of formal revision or subterranean reform, that newly challenges the principle of free access at the point of use for NHS primary and secondary care services. Nor, since the abolition of tax relief on private medical insurance for those aged over 60 in 1997, have there been initiatives to encourage the expansion of the private pay sector. Moreover, the increase in NHS funding through the 2000s reversed 
potential policy drift that might have led more people, demoralized by extended waiting times for treatment, to turn to the pay sector. Yet, this continuity should not be seen as simple and uncontested. The significant hike in public spending was not a path dependent decision based on previous budgeting patterns. In addition there were, and remain, those who advocate alternative policy designs. Radical ideas to shift to an insurance-based system were floated in government circles in the early Thatcher era. These were quickly dismissed, but the Conservative party has previously embraced ideas that would foster the growth of the pay sector. Margaret Thatcher's preference for a "flourishing private sector" alongside the NHS has remained unfulfilled, but it will be crucial to see whether the post-Cameron Conservatives revert back to positions such as awarding tax breaks to people purchasing private insurance. ${ }^{94}$ As it is,conservative think tanks, such as Civitas, continue to promote the introduction of individual payments for NHS access, and it is quite conceivable that a future government might, for example, use the cover of austerity to deflect blame and introduce charges for access to GPs to help cover projected funding gaps for the NHS. ${ }^{95}$ Further, if the slowdown of the growth of public funding since 2010 continues that might lead to substantive policy drift and a revival of the private pay sector. ${ }^{96}$

For now English health care continues to be dominantly publicly funded and the risk of paying for care remains collectivized rather than borne by individuals. Yet, for some commentators such as Pollock this disguises how the actions of the Coalition Government "reduced the NHS to little more than a public funding stream", with the constituent parts such as Monitor and CCGs effectively "market bodies" ${ }^{97}$ Hunter agrees that public funding does not equate with a commitment to public service on the part of the for profit corporate care providers "who stand to gain most from the changes" introduced by the HSC. ${ }^{98}$ And, certainly, while the funding dimension 
remains true to the "Beveridgian" ideal type the same cannot be said of the provider stream. Here there have been distinctive changes, most obviously the influx of private providers treating NHS patients. ${ }^{99}$ In hindsight, the organization of the provider side did see a path departing revision, if in the form of an entering wedge rather than comprehensive change, when the Thatcher government split the NHS's purchasers and providers. That division did not transform matters as quickly as reform advocates hoped, but subsequent policy layering, furthered by the HSC, has increased the access of private providers to NHS funds.

Some argue that there is less importance to this than meets the eye: According to Julian Le Grand, a prominent adviser to Tony Blair, "as far as the general public is concerned, it doesn't matter whether services are provided by private or public" providers. ${ }^{100}$ Certainly, this contracting out of work is different from "the case of load shedding" where "the performance as well as the responsibility of public tasks no longer belongs to the public sector." ${ }^{101}$ In an interview in 2002, then Labour Secretary of Health Alan Milburn, insisted, "If I can get a private-sector hospital to treat an NHS patient, then for me the person remains an NHS patient. Why? Because the person is being treated according to NHS values."102 For Milburn, engaging the private sector to do NHS work was a means of shoring up the NHS and improving popular perception of the public sector, so reducing the appeal of the private pay sector. ${ }^{103}$ Nevertheless, it remains the case that there has been some transfer of resources from the public to private sectors, which constitutes a shift along the continuum towards privatization. ${ }^{104}$ Moreover, the marketization of care has changed the incentive structure for NHS providers. Foundation Trusts are now at least quasicommercial institutions, competing not just with private providers but also with each other, driven by the principle that money follows patients. 
Yet, while the outsourcing of secondary care NHS work to the private sector has increased, the immediate scope for further growth should not be exaggerated. While defending the use of private sector providers to shorten waiting times, chief executive of NHS England, Simon Stevens, added, "Most services in this country are delivered by the NHS and that's going to continue to be the case under any foreseeable future". ${ }^{105}$ Interestingly, NHS England's recent five-year plan did not call for further competition, but emphasized the need for better integration of NHS care and, while competition and integration are not mutually exclusive, they are not natural bedfellows. ${ }^{106}$ In addition, austerity in financing is a double-edged sword. Delays in NHS treatment might drive people to the private pay sector, but tight budgets are not conducive to private providers taking more NHS work as the payments available do not leave much room for profit making. ${ }^{107}$

In the longer term the full impact of the changes to the provider stream will depend on how some of the changes in the regulatory dimension evolve. Of the three streams this is the most difficult to judge, with fewer quantifiable measures to hand. Furthermore, the implications of regulatory policy change are not always clear. The OECD contrasted "social equity" with "consumer sovereignty". ${ }^{108}$ The NHS still treats patients equally, but the promotion of patient choice potentially undermines equity if it advantages those patients with a more confident voice, though Le Grand points to evidence that that "the less powerful and less well off" value choice as much as their wealthier counterparts. ${ }^{109}$ Prime Minister Blair, in fact asserted that NHS patient choice would improve equity: "Choice mechanisms enhance equity by exerting pressure on low-quality or incompetent providers.... Choice leads to higher standards. The overriding principle is clear. We should give poorer patients... the same range of choices the rich have always enjoyed". ${ }^{110}$ This is not entirely logical 
since the rich still have the choice to use the private pay sector that the poor do not, and patient choice potentially introduces an element of "consumer sovereignty" into the relationship between patients and providers. As it is, choosing a secondary care provider remains some distance from choosing a holiday hotel on Trip Advisor, but the HSC made a clear effort to get GPs and patients to alter their behavior. Similar uncertainty surrounds the extent to which Foundation Trusts will attempt to raise revenue from pay patients. Pollock asserts that the HSC "sets out that it expects" Trusts "to be $51 \%$ NHS and $49 \%$ private in terms of the income and services provided." ${ }^{111}$ Here Pollock assumes that the rule change did not just allow change, but was also a form of policy conversion that altered the incentives for Trusts that will drive them to behave differently over time. Thus far there are only isolated examples of Trusts getting close to the 49 per cent figure, but the significance of this change needs monitoring as it potentially incentivizes Trusts to shift resources from NHS patients to pay beds.

\section{CONCLUSION}

Breaking down debate about privatization into an investigation of the three dimensions of funding, provision and regulation does not provide a universal

translator making sense of the "Tower of Babel", surrounding that debate. ${ }^{112}$ Viewing things along these three dimensions, however, and thinking about the different levers of policy change, the importance of accumulated incremental change and the uneven manner in which change is actually implemented does facilitate a discussion that is not based on either overstated exclamations of what particular reforms will mean nor an underestimation of what they might mean.

Analyzing developments across the three different dimensions of health care systems indicates that a policy trajectory can change in one stream but either less so 
or not at all in another. The level of state funding of health care increased in real terms through the 2000s and even as that growth has halted the state's share of health care spending relative to private spending has been constant. On the other hand, the purchaser - provider split has, over time, reshaped the provider side and led to increased competitive pressures, even on the majority of providers who remain public organizations. Finally, the changes made to how the state regulates patients and providers and how they interact with each other have the potential to alter behavior in a way that would increase the marketization effect of the changes to the provider stream, but this has not materialized in a wholesale manner as yet.

An instructive comparison in understanding the complexity of the English health care arrangements and the ambiguity in interpreting what is meant by privatization is with President Bush's attempt at Social Security reform in 2005. However Bush framed his plan, it did constitute a move to partially privatize the system. ${ }^{113}$ It would have simultaneously changed the manner in which the scheme was funded and individualized risk. That reform effort failed, while the third rail in English public life has undergone considerable change. Reformers, however, have avoided threatening the collectivization of risk in what remains a "national treasure".

Importantly, the analytical framework employed in this paper has relevance beyond the case of English health care. The paper does not claim that the patterns of continuity and change witnessed in England provide a guide to developments elsewhere, but it does lay out a model for studying those developments. First, the health care state literature is most usefully applied when its ideal types are broken down into different dimensions and the 'ideal' is qualified by an acknowledgement that there can be discrepancy from that ideal in one dimension or another. Second, combining the health care state literature and the 
policy change literature allows us to better grasp that important change can occur, which should be properly appreciated but which falls short of a paradigm shift. Finally, it is vital to try to provide an intelligible conceptualization of the terms that are under debate, as too often key expressions such as 'privatization' (or 'socialization') are used with insufficient clarity.

\section{References}

${ }^{1}$ Jacky Davis, John Lister and David Wrigley, NHS For Sale: Myths, Lies and Deception (London: The Merlin Press, 2015); Colin Leys and Stewart Player, The Plot Against the NHS (Pontypool, Wales: The Merlin Press, 2011)

${ }^{2}$ Secretary of State for Health, Working for Patients (London: HMSO, 1989)

${ }^{3}$ Allyson Pollock, NHS plc: The Privatisation of Our Health Service (London; Verso, 2005).

${ }^{4}$ Ipsos Mori, Public Perceptions of the NHS and Social care Tracker Survey, Winter 2013 Wave, 2014, accessed at https://www.ipsos-mori.com/Assets/Docs/sri-healthnhstracker-report-winter2013.pdf, 23 November 2015

${ }^{5}$ Robert Winnett, "David Cameron: Tories are the party of the NHS", 4 January 2010, The Telegraph, accessed at http://www.telegraph.co.uk/news/election2010/6932043/David-Cameron-Tories-are-the-party-of-the-NHS.html, 7 March 2017

${ }^{6}$ On the process see Nicholas Timmins, Never Again? London: The King's Fund, 2012). For debates about the outcome see, David Hunter, "A response to Rudolf Klein" A Battle May Have Been won but Perhaps Not the War", Journal of Health Politics, Policy and Law, 38: 4 (2013); 871-877; Rudolf Klein, “The Twenty-Year over England's National Health Service: A Report from the Battlefield", Journal of 
Health Politics, Policy and Law, 38: 4 (2013); 849-869; Allyson Pollock, David Price, Peter Roderick, Tim Treuherz, David McCoy, Martin McKee, Lucy Reynolds. "How the Health and Social Care Bill 2011 would End Entitlement to Comprehensive Health Care in England", The Lancet 379: 9814 (2012): 387-389

${ }^{7}$ On this important topic see Scott Greer and Alan Trench, "Intergovernmental Relations and Health in the Devolved United Kingdom," Policy and Politics 21 (2010): 509-529.

${ }^{8}$ Patrick Wintour, "Labour refuses to confirm Miliband wants to 'weaponise' NHS in election", The Guardian, 12 January 2015, accessed at https://www.theguardian.com/politics/2015/jan/12/labour-refuses-confirmmiliband-weaponise-nhs-election-campaign 7 March 2017

${ }^{9}$ Martin Powell and Robin Miller, "Privatizing the English National Health Service: An Irregular Verb?" Journal of Health Politics, Policy and Law 38: 5 (2013): 10511059 , at 1058

${ }^{10}$ Daniel Béland and Alex Waddan, The Politics of Policy Change: Welfare, Medicare, and Social Security Reform in the United States (Washington, DC: Georgetown University Press, 2012); John L. Campbell, Institutional Change and Globalization, (Princeton: Princeton University Press, 2004); Jacob Hacker, "Privatizing Risk without Privatizing the Welfare State: The Hidden Politics of Welfare State Retrenchment in the United States", American Political Science Review 98 (2004): 243-260; Wolfgang Streeck and Kathleen Thelen eds., Beyond Continuity: Institutional Change in Advanced Political Economies, (Oxford: Oxford University Press, 2005)

${ }^{11}$ Viola Burau and Robert Blank, "Comparing Health Policy: An Assessment of Typologies of Health Systems", Journal of Comparative Policy Analysis: Research 
and Practice, 8: 1 (2006): 63-76; Michael Moran, "Understanding the Welfare State: the Case of Health Care", British Journal of Politics and International Relations, 2: 2 (2000): 135-169; OECD, Financing and Delivering Health Care: A Comparative Analysis of OECD Countries (Paris: OECD, 1987) Heinz Rothgang, Mirella Cacace, Lorraine Frisina, Simone Grimmeisen, Achim Schmid, Claus Wendt, The State and Health Care: Comparing OECD Countries, (Basingstoke: Palgrave, 2010); Claus Wendt, Lorraine Frisina and Heinz Rothgang, "Health Care System Types: A Conceptual framework for Comparison", Social Policy and Administration, 43: 1 (2009): 70-90

${ }^{12}$ OECD, Financing and Delivering Health Care, 24

${ }^{13}$ Moran, "Understanding the Welfare State"; Wendt, Frisina and Rothgang, "Health Care System Types”

${ }^{14}$ Ipsos Mori, Public Perceptions of the NHS and Social care Tracker Survey, Winter 2013 Wave, 2014

${ }^{15}$ Gilberto Capano, "Understanding Policy Change as an Epistemological and Theoretical Problem", Journal of Comparative Policy Analysis: Research and Practice, 11: 1 (2009): 7-31; Hacker, "Privatizing Risk without Privatizing the Welfare State"

${ }^{16}$ Streeck and Thelen eds., Beyond Continuity; A. Weiss and E. Woodhouse, "Reframing Incrementalism: A Constructive Response to the Critics", Policy Science, 25 (1992), 255-73

${ }^{17}$ Calum Paton, "Garbage-can Policy-making Meets Neo-liberal Ideology: Twenty Five Years of Redundant Reform of the English National Health Service”, Social Policy and Administration 48: 3 (2014): 319-342, at 339 
${ }^{18}$ Hacker, "Privatizing Risk without Privatizing the Welfare State"; Jacob Hacker, Kathleen Thelen, and Paul Pierson, "Drift and Conversion: Hidden Faces of Institutional Change", in James Mahoney and Kathleen Thelen eds., Advances in Comparative-Historical Analysis (Cambridge: Cambridge University Press, 2015) $180-208$

${ }^{19}$ Douglas Jaenicke and Alex Waddan, "President Bush and Social Policy: The Strange Case of the Medicare Prescription Drug Benefit”, Political Science Quarterly, 121 (Summer, 2006), 217 - 240

${ }^{20}$ OECD, Financing and Delivering Health Care

${ }^{21}$ Moran, "Understanding the Welfare State"; Wendt, Frisina and Rothgang, "Health Care System Types”

${ }^{22}$ Wendt, Frisina and Rothgang, "Health Care System Types”, 71

${ }^{23}$ Richard Janssen and Jan van der Made, "Privatisation in Health Care: Concepts, Motives and Policies”, Health Policy, 14 (1990), 191-202

${ }^{24}$ Paul Starr, "The Meaning of Privatization”, Yale Law and Policy Review, 6, (1988), 6-41, at 17

${ }^{25}$ John Tudor Hart, The Political Economy of Health Care: Where the NHS came from and where it could lead, (Bristol: The Policy Press, 2010), 2

${ }^{26}$ This excludes dental and ophthalmic care where public funding and provision has significantly declined.

${ }^{27}$ Emma Hawe, and Lesley Cockroft, OHE Guide to UK Health and Health Care Statistics, (London: Office of Health Economics, 2013), 51

${ }^{28}$ This equity does not extend to health outcomes (see, Hunter, 2008: 25).

${ }^{29}$ Secretary of State for Health, Equity and Excellence: Liberating the NHS.

(London: HMSO, 2010), 3 
${ }^{30}$ OECD, OECD Health Statistics, 2015, Paris: OECD, accessed at

http://stats.oecd.org/Index.aspx?DataSetCode=SHA 6 March 2017

${ }^{31}$ Tony Delamothe, “A Comprehensive Service”, British Medical Journal, 336, $\left(14^{\text {th }}\right.$ June, 2008), 1344-1345 at 1344

${ }^{32}$ Daniel Béland, Philip Rocco and Alex Waddan, 2016. "Reassessing Policy Drift:

Social Policy Change in the United States," Social Policy and Administration, 50 (2):

201-218; Hacker, "Privatizing Risk without Privatizing the Welfare State"

${ }^{33}$ Rothgang, Cacace, Frisina, Grimmeisen, Schmid, Wendt, The State and Health

Care, 84

${ }^{34}$ Office for National Statistics, Expenditure on Healthcare in the UK, 2013, (Surrey:

Office for National Statistics, 2015), 6

${ }^{35}$ Commission on the Future of Health and Social Care in England, The UK Private

Health Market, (London: The King's Fund, 2014), 3

${ }^{36}$ OECD, OECD Health Statistics,

${ }^{37}$ Rowena Crawford, Carl Emmerson and Gemma Tetlow, A Survey of Public

Spending in the UK, Institute for Fiscal studies, (London: IFS Briefing Note BN43, 2009)

${ }^{38}$ OECD, OECD Health Statistics

${ }^{39}$ Ibid.

${ }^{40}$ LaingBuisson, "Outsourcing of healthcare services to the independent sector has grown during the Coalition, according to latest LaingBuisson research”, Press Release, 26 February 2015, accessed at https://www.laingbuisson.co.uk/MediaCentre/PressReleases/LaingBuissonReview27 $\underline{\text { ed.aspx }} 1$ August 2015 
${ }^{41}$ Rob Baggot, "Conservative Health Policy: Change, Continuity and Policy Influence" in Hugh Bochel ed. The Conservative Party and Social Policy, Bristol: The Policy Press, 2011), 77-96

${ }^{42}$ Conservative Party, Conservative Party Manifesto: It's Time for Action, 2005, accessed at http://www.politicsresources.net/area/uk/ge05/man/manifesto-uk2005.pdf 1 August 2015

${ }^{43}$ Nicholas Timmins, “Patients’ Passports Pop Up Again”, bmj.com, 23 April 2005 accessed at http://www.ncbi.nlm.nih.gov/pmc/articles/PMC556332/pdf/bmj33000925.pdf 1 August 2015

44 The King's Fund, “The King's Fund statement in response to Conservative Party health policy consultation document, Setting Patients Free, Press Release, 4 June 2003, accessed at http://www.kingsfund.org.uk/press/press-releases/kings-fund-

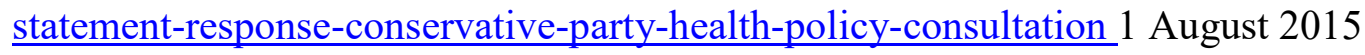
${ }^{45}$ David Cameron, "Full text of David Cameron's speech on the NHS delivered to the King's Fund", The Guardian, 4 January 2006, accessed at http://www.theguardian.com/society/2006/jan/04/health.conservativeparty 5 August 2015 ${ }^{46}$ Ibid.

${ }^{47}$ Secretary of State for Health, Equity and Excellence, 37

${ }^{48}$ Secretary of State for Health, Working for Patients

${ }^{49}$ Cook quoted in Rudolf Klein The New Politics of the NHS: from Creation to Reinvention, (Oxford: Radcliffe Publishing, 2006) 153; Alain Enthoven, Reflections on the Management of the National Health Service: An American looks at incentives 
to efficiency in health service management in the UK, (London: The Nuffield Provincial Hospitals Trust, 1985)

${ }^{50}$ Secretary of State for Health, The New NHS: Modern, Dependable (London: HMSO, 1997)

${ }^{51}$ Secretary of State for Health, The NHS Plan (London: HMSO, 2000), 56

${ }^{52}$ Ibid. 96

${ }^{53}$ Secretary of State for Health, Delivering the NHS Plan, (London: HMSO, 2002) 20

${ }^{54}$ Ibid, 4-5; For more on the organizational changes on the purchaser side leading to the creation of PCTs, see Klein, The New Politics of the NHS, 194-5.

${ }^{55}$ David Hunter, The Health Debate, (Bristol: The Policy Press, 2008), 69; Pollock, NHS plc, 242-7

${ }^{56}$ Chris Naylor and Sarah Gregory, Briefing: Independent Sector Treatment Centres, (London: King's Fund, 2009)

${ }^{57}$ Ian Greener, Healthcare In the UK: Understanding Continuity and Change, (Bristol: The Policy Press, 2009), 220

${ }^{58}$ Laura Brereton and James Gubb, Refusing Treatment: The NHS and Market-based Reform, (London: Civitas: Institute for the Study of Civil Society, 2010)

${ }^{59}$ Sandeepa Arora, Anita Charlesworth, Elaine Kelly and George Stoye, Public Payment and Private Provision: The Changing Landscape of Health Care in the 2000s, (London: The Institute for Fiscal Studies and the Nuffield Trust, 2013), 4 ${ }^{60}$ Ibid. 14

61 Elaine Kelly and Gemma Tetlow, Choosing the Place of Care: The Effect of Patient Choice on Treatment Location in England, 2003-2011, (London: Institute for Fiscal Studies and the Nuffield Foundation, 2012),

${ }^{62}$ Anna Dixon, Nicholas Mays and Lorelei Jones, Understanding New Labour 
Market Reforms of the English NHS, (London: The King's Fund, 2011), 1

${ }^{63}$ Timmins, Never Again

${ }^{64}$ Secretary of State for Health, Equity and Excellence, 35

${ }^{65}$ Judith Smith and Natasha Curry. 2011. "Commissioning," in Dixon, Mays and Jones eds, Understanding New Labour Market Reforms of the English NHS, 30-51 ${ }^{66}$ Greener, Healthcare In the UK, 221

${ }^{67}$ Li Bing, A. Akintoye, C.J Edwards, and C. Hardcastle, 2005. "The Allocation of Risk in PPP/PFI Construction Projects in the UK", International Journal of Project Management, 23 (2005): 25-35

${ }^{68}$ House of Commons Treasury Committee, Private Finance Initiative, (London: The Stationery Office, August 2011); Robert Winnett, "PFI reborn with pledge that this time the taxpayer won't lose out", The Telegraph, 3 December 2012, accessed at http://www.telegraph.co.uk/news/politics/9720404/PFI-reborn-with-pledge-that-thistime-the-taxpayer-wont-lose-out.html 5 May 2016

${ }^{69}$ Robert Mendick, Laura Donnelly and Ashley Kirk, "The PFI hospitals costing NHS £2bn every year”, The Daily Telegraph, 18 July 2015. For a critique of the need for PFI see, Allyson Pollock, Jean Shaoul and Neil Vickers, "Private finance and "value for money" in NHS hospitals: a policy in search of a rationale?" British Medical Journal, 324 (18 May 2002), 1205-9,

${ }^{70}$ For a detailed discussion of these changes see Gwyn Bevan, "Regulation and System Management", in Dixon, Mays and Jones eds, Understanding New Labour Market Reforms of the English NHS, 89-111

${ }^{71}$ Andrew Sparrow, "Milburn Wants to End Pay Beds", The Daily Telegraph, 15 July 2002 
${ }^{72}$ Adam Scott, Tom Stevenson and Victor Chua, "The profitability of private patients", Health Services Journal, 27 September 2012, accessed at https://www.hsj.co.uk/topics/efficiency/the-profitability-of-privatepatients/5049176.article 21 November 2016

${ }^{73}$ Julian Le Grand, The Other Invisible Hand: Delivering Public Services Through Choice and Competition, (Woodstock, Oxfordshire: Princeton University Press, 2007)

${ }^{74}$ For a debate about the merits of targets see Gwyn Bevan, "Have Targets Done More Harm Than Good in the English NHS? No", and James Gubb, "Have Targets Done More Harm Than Good in the English BHS? Yes”, British Medical Journal, 338:a3130, (2009) accessed at http://www.bmj.com/content/338/bmj.a3130 10 June 2016; Le Grand, The Other Invisible Hand

${ }^{75}$ Le Grand, The Other Invisible Hand

${ }^{76}$ Secretary of State for Health, Delivering the NHS Plan, 7

${ }^{77}$ Department of Health, Report on the National Patient Choice Survey, EnglandFebruary 2010, accessed at http://www.dh.gov.uk/en/Publicationsandstatistics/Publications/PublicationsStatistics $\underline{\text { DH } 116958} 7$ July 2016; Anna Dixon, Ruth Robertson, John Appleby, Peter Burge, Nancy Devlin and Helen Magee, Patient Choice: How Patients Choose and How Providers Respond, (London: The King's Fund, 2010) xv-xvi

${ }^{78}$ See, for example, the NHS Choice website for how patients can access evidence about their local NHS services (NHS n.d.).

${ }^{79}$ Kenneth Arrow, "Uncertainty and the Welfare Economics of Medical Care", The American Economic Review, 53: 5 (1963): 941-973

${ }^{80}$ National Audit Office. Monitor: Regulating NHS Foundation Trusts, (London: 
National Audit Office, 2014), 5

${ }^{81}$ Sue Richards, "The government is trying to privatize the NHS through backdoor regulations", The Guardian, 5 March 2013

${ }^{82}$ Sofia Lind, "First CCGs under investigation for breach of competition regulations", Pulse, 11 October 2013, accessed at http://www.pulsetoday.co.uk/news/commissioning/commissioning-topics/ccgs/firstccgs-under-investigation-for-breach-of-competition-regulations/20004715.fullarticle 27 November 2016

${ }^{83}$ Matthews-King, Alex, 2014. "Practices who fail to offer choice to face crackdown from CCGs following Monitor ruling”, Pulse, September $25^{\text {th }}$, accessed at http://www.pulsetoday.co.uk/news/commissioning-news/practices-who-fail-to-offer$\underline{\text { choice-to-face-crackdown-from-ccgs-following-monitor-ruling/20008006.fullarticle }}$ 28 November 2016

${ }^{84}$ NHS England, Five Year Forward View, October 2014, accessed at https://www.england.nhs.uk/wp-content/uploads/2014/10/5yfv-web.pdf 28

November 2016, 12-13

${ }^{85}$ Secretary of State for Health, Equity and Excellence

${ }^{86}$ Department of Health, A Simple Guide to Payment by Results, 2013, accessed at https://www.gov.uk/government/uploads/system/uploads/attachment_data/file/21315

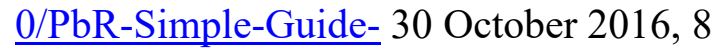

${ }^{87}$ Michael Rawlins, "NICE: Moving Onward”, New England Journal of Medicine, 369: 1 (2013), 2-5

${ }^{88}$ National Institute for Health and Care Excellence, What We Do, accessed at, https://www.nice.org.uk/about/what-we-do, 23 November 2016 
${ }^{89}$ Foundation Trust Network, How NHS Providers Use Non-NHS Income to Improve Patient Services, (London: Foundation Trust Network, 2014), 2

${ }^{90}$ Burnham quoted in Helen Briggs, “'Planned 49\% limit' for NHS private patients in England”, BBC News website, 27 December 2011, accessed at http://www.bbc.co.uk/news/health-16337904 30 October 2016 ${ }^{91}$ Gill Plimmer and Sarah Neville, "NHS Income from private patients rises sharply", FT.com, 26 September 2013, accessed at http://www.ft.com/cms/s/0/0067138c-268911e3-9dc0-00144feab7de.html\#axzz3hw0vnDaq 10 December 2015

${ }^{92}$ Nicholas Watt, "Income from private patients soars at NHS hospital trusts", The Guardian, 19 August 2014. One reason London's hospitals are distinctive is the attraction of the city to non-UK residents. See, for example, the Royal Free Hospital's web page dedicated to attracting overseas, fee paying, patients http://www.royalfreeprivatepatients.com/international-patients/

${ }^{93}$ Klein, "The Twenty-Year over England's National Health Service”, 849

${ }^{94}$ Margaret Thatcher, The Downing Street Years, (London: Harper Collins, 1993), 606; Howard Glennerster and Robert Lieberman, "Hidden Convergence: Toward a Historical Comparison of U.S. and U.K. Health Policy", Journal of Health Politics, Policy and Law, 36: 1 (2011), 5-31, at 16-18; Toby Helm and Rajeev Syal, 2009. "Key Tory MPs backed call to dismantle the NHS", The Guardian, 16 August 2009. ${ }^{95}$ Christoh Lees and Edmund Stubbs, NHS Contribute Extra: A return to the NHS's core values, (London: Civitas, 2015); Neil Roberts, "GP charges for patients could become necessary, finance experts warn", GPonline, 5 August 2015, accessed at http://www.gponline.com/gp-charges-patients-become-necessary-finance-experts-

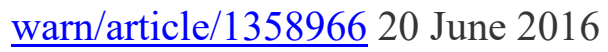


${ }^{96}$ Rudolf Klein, "The NHS in the Age of Anxiety: Rhetoric and Reality", British Medical Journal, 347: f5104 (21 August 2013), accessed at http://www.bmj.com/content/347/bmj.f5104 20 November 2015

${ }^{97}$ Allyson Pollock, "Will Politicians be the Architects or the Destroyers of the NHS?" The Lancet, 385: 9974 (28 March 2015): 1171-2

${ }^{98}$ Hunter, “A Response to Rudolf Klein”, 873

${ }^{99}$ Arora, Charlesworth, Kelly and Stoye, Public Payment and Private Provision;

Denis Campbell, "NHS agrees largest-ever privatization deal to tackle backlog", The Guardian, 12 March 2015.

${ }^{100}$ LeGrand quoted in Hannah Brown, “Tony Blair's legacy for the UK's National health Service”, The Lancet, 369: 9574 (19 May 2007), 1679-1682 at 1682

101 Janssen and van der Made, "Privatisation in Health Care", 192

102 Nicholas Timmins, "A Time for Change in the British NHS: An interview with Alan Milburn", Health Affairs, 21: 3 (May 2002), 129-135 at 130

103 Jane Gingrich, Making Markets in the Welfare State: The Politics of Varying Market Reforms, (Cambridge: Cambridge University Press, 2011), 99

${ }^{104}$ Starr, "The Meaning of Privatization"

${ }^{105}$ Stevens quoted in Denis Campbell, "NHS boss Simon Stevens defends privatization", The Guardian, 23 October 2014.

${ }^{106}$ NHS England, Five Year Forward View

${ }^{107}$ Nick Krachler and Ian Greer, "When Does Marketization Lead to Privatization?

Profit-making in English Health Services after the 2012 Health and Social Care Act”, Social Science and Medicine, 124 (2015), 215-223

${ }^{108}$ OECD, Financing and Delivering Health Care

${ }^{109}$ Le Grand, The Other Invisible Hand, 51-4 
${ }^{110}$ Blair quoted in Dixon, Robertson, Appleby, Burge, Devlin and Magee, Patient

Choice, 2

${ }^{111}$ Pollock, "Will Politicians be the Architects or the Destroyers of the NHS?" It is a little misleading to conflate "income" and "services" as "private" revenue can come from things like car park charges, catering or rental of surplus property.

112 Powell and Miller, "Privatizing the English National Health Service"

${ }^{113}$ Béland and Waddan, The Politics of Policy Change 